\title{
PENGARUH LAYANAN INFORMASI TERHADAP PENYESUAIAN DIRI SISWA
}

Oleh :

\author{
Wa Ode Kasna ${ }^{1)}$, La Ode Muharam ${ }^{2)}$, Sudarmi Suud B ${ }^{3)}$ \\ 1) 2) 3) Jurusan Bimbingan dan Konseling \\ Fakultas Keguruan dan Ilmu Pendidikan, Universitas Halu Oleo \\ Email: waodekasna95@gmail.com
}

\begin{abstract}
ABSTRAK
Tujuan penelitian ini adalah untuk meningkatkan penyesuaian diri siswa SMP Negeri 1 Loghia Kabupaten Muna. Jenis penelitian ini adalah penelitian eksperimen dengan desain pre eksperimen. Subjek dalam penelitian ini adalah sebanyak 19 siswa kelas VII SMP Negeri 1 Loghia Kabupaten Muna. Metode analisis data menggunakan uji Wilcoxon Match Pairs Test. Hasil penelitian menunjukkan layanan informasi dapat meningkatkan penyesuaian diri siswa kelas VII SMP Negeri Loghia, hal ini ditunjukkan dengan nilai sig. = 0,000 pada taraf signifikan $5 \%$ atau $\alpha=0,05$. Berdasarkan data nilai signifikansi tersebut dapat disimpulkan bahwa layanan informasi berpengaruh terhadap peningkatan penyesuaian diri siswa SMP Negeri 1 Loghia Kabupaten Muna.
\end{abstract}

Kata Kunci: Layanan Informasi, Penyesuaian Diri Siswa

THE EFFECT OF INFORMATION SERVICE ON STUDENTS SELF ADJUSTMENT

\begin{abstract}
The purpose of the research was to improve the students self adjustment in SMP Negeri 1 Loghia Kabupaten Muna. This was pre-experimental research. The subjects of the research were 19 students who have been sitting in the seventh graders of SMP Negeri 1 Loghia Kabupaten Muna. The data were analyzed by Wilcoxon Match Pairs Test. The findings of the research show that information service is able to improve the students self adjustment in SMP Negeri 1 Loghia Kabupaten Muna. Its significant value is $=0.000$ with the level of significant is $5 \%$ or a $=0.05$. based on the data of significant value, it can therefore be concluded that guidance and counseling information services have effect on developing the students self adjustment in SMP Negeri 1 Loghia Kabupaten Muna.
\end{abstract}

Keywords: Information Service, The Students Self Adjustment. 


\section{Pendahuluan}

Kesiapan siswa dalam mengikuti proses pendidikan atau menerima pembelajaran menjadi dasar bagi guru untuk menyampaikan pelajaran. Kesiapan siswa tidak hanya dilihat dari aspek fisik atau kelengkapan sarana belajar seperti seragam, sepatu, buku dan alat tulis tetapi harus pula dilihat dari aspek siswa sebagai manusia yang memiliki pikiran dan perasaan. Dalam hal ini, aspek psikologis siswa harus menjadi perhatian utama untuk mengetahui sejauh mana kesiapan siswa mengikuti proses pendidikan.

Siswa Sekolah Menengah Pertama (SMP) merupakan usia remaja yang sedang dalam proses berkembang ke arah kematangan dan kemandirian baik secara pribadi maupun sosial. Dalam proses perkembangan tersebut, seorang siswa perlu menyesuaikan diri dengan lingkungan yang ada. Schneiders (dalam Semiun, 2006) menyebut banyaknya realitas dan situasi sosial yang harus dihadapi oleh remaja menyebabkan banyak menuntut remaja untuk berperilaku efektif tidak mampu mengatasi permasalahan yang timbul di lingkungan, seperti yang dapat dilihat pada aspekaspek penyesuaian sosial yaitu remaja saling mengenal dan menghormati orang lain (recognition) yang terwujud dalam perilaku siswa yang tidak mengejek dan harus dapat menghormati orang lain, melibatkan diri dalam berelasi (participation) seperti tidak memilih-milih teman dalam pergaulan, minat dan simpati terhadap kesejahteraan orang lain (social approval) yaitu peka terhadap masalah orang lain sehingga dapat saling tolong menolong, mementingkan kepentingan orang lain (altruisme) yakni dapat menerima kelebihan dan kekurangan orang lain dan menghormati nilai-nilai yang berlaku di lingkungan (conformity) sehingga dapat diterima di lingkungannya. Salah satu upaya yang dapat dilakukan untuk mengatasi ketidakmampuan siswa dalam melakukan penyesuaian diri di sekolah adalah melalui bimbingan kelompok.

Penyesuaian diri (self adjustment) sebagai suatu proses dimana individu berusaha keras untuk mengatasi atau menguasai kebutuhan dalam diri, ketegangan, frustasi dan konflik, tujuannya untuk mendapatkan keharmonisan dan keselarasan antara tuntutan lingkungan di mana dia tinggal dengan tuntutan di dalam dirinya. Penyesuaian diri merupakan upaya individu untuk dapat hidup aman dan nyaman dalam mencapai keharmonisan antara dirinya sebagai individu dengan lingkungannya yang berlangsung secara terus- menerus. Dengan siswa mampu menyesuaikan diri maka memunyai kemungkinan lebih besar untuk mencapai prestasi yang optimal. Siswa yang berhasil dalam menyesuaikan diri adalah siswa yang mampu berinteraksi secara aktif dengan lingkungannya sehingga siswa tersebut tidak mendapatkan kesulitan-kesulitan dalam menyesuaikan diri dan meskipun terdapat kesulitankesulitan dalam penyesuaian diri di sekolah, siswa akan dapat mengatasinya (Schneiders dalam Astuti, 2000: 84).

Namun tidak jarang ditemui fenomena pada siswa yang mengalami kesulitan dalam berhubungan sosial, baik kurangnya kemampuan siswa dalam bergaul, beradaptasi dengan lingkungan baru, merasa minder, siswa yang sulit memulai pertemanan dengan orang baru, sulit berkomunikasi dengan guru, dan tidak berani mengungkapkan pendapat baik secara pribadi dengan teman maupun di depan umum.

Berdasarkan pra penelitian di SMP Negeri 1 Loghia Kabupaten Muna diperoleh hasil bahwa terdapat perilaku siswa yang teridentifikasi memiliki penyesuaian diri di sekolah yang buruk. Beberapa contoh perilaku tersebut yaitu: terdapat siswa yang mengolok-olok temannya saat menyampaikan pendapat, terdapat siswa yang malu-malu ketika mengungkapkan pendapatnya, terdapat siswa yang tidak mau memberikan bantuannya saat ada teman yang sedang tertimpa musibah, terdapat siswa yang tidak mampu memberikan tanggapan atas masalah yang sedang dialami temannya, terdapat siswa yang tidak disiplin terhadap tata tertib peraturan di sekolah. Perilaku penyesuaian diri yang buruk atau rendah tersebut tentu tidak dapat diabaikan karena memiliki dampak negatif baik bagi siswa itu sendiri dan juga bagi lingkungan di sekolah. Dampak negatif bagi siswa yaitu dijauhi oleh temantemannya, bila perilakunya melanggar aturan maka dapat diberikan hukuman dari sekolah dan dijauhi oleh teman-temannya. Dampak negatif bagi lingkungan sekolah yakni mengganggu ketertiban dan kedisiplinan di sekolah, mengganggu teman dan kegiatan pembelajaran baik saat di kelas maupun di lingkungan sekolah dan terjadinya ketidakharmonisan dalam hubungan sosial di lingkungan sekolah.

Dalam memberikan pemahaman tentang penyesuaian diri yang baik di sekolah tidak terlepas dari peran layanan bimbingan dan konseling (BK). Bimbingan dan konseling di sekolah bertujuan membantu siswa sebagaimana dikemukakan oleh 
Walgito (2004: 5), bahwa dalam bimbingan dan konseling, guru BK dituntut untuk dapat memberikan bantuan ataupun pertolongan kepada individu atau sekumpulan individu dalam menghindari atau mengatasi kesulitan-kesulitan dalam kehidupannya, agar individu atau sekumpulan individu-individu itu dapat mencapai kesejahteraan hidupnya.

Salah satu layanan bimbingan dan konseling adalah layanan informasi. Prayitno (2004: 11) menjelaskan bahwa layanan informasi adalah suatu kegiatan layanan yang diberikan dengan tujuan memberikan pemahaman kepada individu-individu yang berkepentingan tentang berbagai hal yang diperlukan untuk menjalankan suatu tugas atau kegiatan yang dikehendaki.

Lebih lanjut, Yusuf dan Nurihsan (dalam Rahayu, 2012: 29) menyatakan layanan informasi sebagai upaya membantu individu dalam perencanaan, pengembangan dan pemecahan masalah-masalah pribadi, sosial, belajar dan karir serta merupakan suatu layanan pemenuhan kebutuhan perkembangan individu sebagai proses integral dari program pendidikan. Layanan informasi ialah layanan bimbingan dan konseling yang memungkinkan klien menerima dan memahami berbagai informasi yang dapat dipergunakan sebagai bahan yang sangat penting bagi siswa. Penyajian informasi dalam rangka program bimbingan dimana kegiatan membantu siswa dalam mengenali lingkungannya, mengenali berbagai perilaku yang dapat dikembangkan dan memahami perilaku yang sesuai dengan harapan lingkungan. Penyajian informasi untuk memberikan wawasan kepada para siswa sehingga dapat menggunakan informasi itu baik untuk mencegah dan mengatasi berbagai kesulitan yang dihadapinya.

Berdasarkan penjelasan tersebut, peneliti bermaksud membantu siswa mengatasi kesulitan dalam penyesuaian diri baik dengan diri dan lingkungannya melalui sebuah layanan bimbingan dan konseling yaitu layanan informasi dalam penelitian dengan judul "Pengaruh Layanan Informasi Terhadap Penyesuaian Diri Siswa SMP Negeri 1 Loghia Kabupaten Muna”. Adapun tujuan yang hendak dicapai dalam penelitian ini adalah untuk mengetahui apakah ada pengaruh layanan informasi terhadap penyesuaian diri siswa SMP Negeri 1 Loghia Kabupaten Muna.

Ali dan Asrori (2008: 196) mengemukakan bahwa setidaknya ada 3 sudut pandang tentang penyesuaian diri yaitu: 1) penyesuaian diri sebagai adaptasi (adaptation) yaitu penyesuaian diri yang lebih mengarah pada penyesuaian secara fisik, fisiologis dan biologis, 2) penyesuian diri sebagai bentuk konformitas (conformity) yaitu penyesuaian diri yang mencakup konformitas terhadap suatu norma-norma yang berlaku, dan 3) penyesuaian diri sebagai usaha penguasaan (mastery) yaitu kemampuan untuk merencanakan dan mengorganisasikan respon dalam cara-cara tertentu sehingga konflik-konflik, kesulitan dan frustasi tidak terjadi.

Selanjutnya, Willis (2008: 55) mengemukakan pengertian penyesuaian diri ialah kemampuan seseorang untuk hidup dan bergaul secara wajar terhadap lingkungannya, sehingga ia merasa puas terhadap dirinya dan terhadap lingkungan. Schneiders (dalam Ali dan Asrori, 2006: 173-175) mengemukakan bahwa penyesuaian diri merupakan suatu proses dinamis yang bertujuan untuk mengubah perilaku individu agar terjadi hubungan yang lebih sesuai antara diri individu dengan lingkungannya.

Berdasarkan pengertian tersebut, dapat disimpulkan bahwa penyesuaian diri adalah suatu proses yang terjadi pada diri individu dalam upaya untuk menguasai tekanan akibat dorongan kebutuhan, usaha memelihara keseimbangan antara pemenuhan kebutuhan dan tuntutan lingkungan dan usaha menyelaraskan hubungan individu dengan realitas lingkungan yang ada di sekitarnya.

Menurut Schneiders (dalam Fatimah, 2006:

53) menyebutkan ciri-ciri dari penyesuaian diri sebagai berikut:

1. Recognition (menghormati dan menerima hakhak orang lain).

Dalam hal ini, individu tidak melanggar hakhak orang lain yang berbeda dengan dirinya, untuk menghindari terjadinya konflik sosial. Ketika kita dapat menghargai dan menghormati hak-hak orang lain maka orang lain akan menghormati dan menghargai hak-hak kita sehingga hubungan sosial antar individu dapat terjalin dengan sehat dan harmonis.

2. Participation (melibatkan diri dalam berelasi).

Setiap individu harus dapat mengembangkan dan melihara persahabatan. Seseorang yang tidak mampu membangun relasi dengan orang lain dan lebih menutup diri dari relasi sosial akan menghasilkan penyesuaian diri yang buruk. Individu ini tidak memiliki ketertarikan untuk berpartisipasi dengan aktivitas di lingkungannya serta tidak mampu untuk mengekspresikan diri mereka sendiri, sedangkan bentuk penyesuaian akan dikatakan baik apabila individu tersebut 
mampu menciptakan relasi yang sehat dengan orang lain, mengembangkan persahabatan, berperan aktif dalam kegiatan sosial serta menghargai nilai-nilai yang berlaku di masyarakat.

3. Social approval (minat dan simpati terhadap kesejahteraan orang lain).

Hal ini dapat merupakan bentuk penyesuaian diri di masyarakat, dimana individu dapat peka dengan masalah dan kesulitan orang lain di sekelilingnya serta bersedia membantu meringankan masalahnya. Selain itu, individu juga harus menunjukkan minat terhadap tujuan, harapan dan aspirasi. Cara pandang ini juga sesuai dengan tuntutan dalam penyesuaian keagamaan (religious adjustment).

4. Altruisme (memiliki sifat rendah hati dan tidak egois).

Rasa saling membantu dan mementingkan orang lain merupakan nilai-nilai moral yang aplikasi dari nilai-nilai tersebut merupakan bagian dari penyesuaian moral yang baik yang apabila diterapkan di masyarakat secara wajar dan bermanfaat maka akan membawa pada penyesuaian diri yang kuat. Bentuk dari sifatsifat tersebut memiliki rasa kemanusian, rendah diri, dan kejujujuran dimana individu yang memiliki sifat ini akan memiliki kestabilan mental, keadaan emosi yang sehat dan penyesuaian yang baik.

5. Conformity (menghormati dan menaati nilainilai integritas hukum, tradisi dan kebiasaan).

Adanya kesadaran untuk mematuhi dan menghormati peraturan dan tradisi yang berlaku dilingkungan maka ia akan dapat diterima dengan baik di lingkungannya.

Dalam penelitian ini penyesuaian diri yang baik dikatakan sebagai penyesuaian diri yang tinggi dan penyesuaian diri yang buruk dikatakan sebagai penyesuaian diri yang rendah. Menurut Asrori (2007: 198), penyesuaian diri yang baik dan penyesuaian diri yang buruk adalah sebagai berikut:

1. Penyesuaian diri yang baik (Positif)

Individu dikatakan memiliki penyesuaian yang baik (well adjusted person) adalah jika individu mampu melakukan respon-respon yang matang, efisien, memuaskan dan sehat. Dikatakan efisien artinya mampu melakukan respon dengan mengeluarkan waktu dan tenaga sehemat mungkin. Dikatakan sehat artinya respon-respon yang dilakukan individu cocok dengan hakikat individu, lembaga atau kelompok individu dan hubungan antara individu dan penciptanya. Bahkan, dapat dikatakan bahwa sifat sehat ini adalah gambaran karakteristik yang paling menonjol untuk melihat atau menentukan bahwa suatu penyesuaian diri itu dikatakan baik).

Sifat sehat ini adalah gambaran karakteristik yang paling menonjol untuk melihat atau menentukan bahwa suatu peyesuaian diri itu dikatakan baik. Sehingga individu yang memiliki penyesuaian diri yang baik adalah yang telah belajar mereaksi terhadap diri dan lingkungannya dengan cara-cara yang matang, efisien, memuaskan dan sehat serta dapat mengatasi konflik mental, frustasi, serta kesulitan pribadi dan sosial tanpa mengembangkan perilaku simtomatik dan gangguan psikosomatik yang mengganggu tujuan-tujuan moral, sosial, agama dan pekerjaan.

2. Penyesuaian diri yang buruk (Negatif)

Kegagalan dalam melakukan penyesuaian diri di sekolah secara positif, dapat mengakibatkan individu melakukan penyesuaian diri di sekolah yang salah. Ada tiga bentuk reaksi dalam penyesuaian diri di sekolah yang salah, yaitu:

a. Reaksi bertahan (defence reaction)

Individu berusaha untuk memertahankan dirinya, seolah-olah tidak menghadapi kegagalan. Ia selalu berusaha menunjukkan bahwa dirinya tidak mengalami kegagalan. Bentuk reaksi bertahan antara lain: 1) rasionalisasi yaitu suatu usaha bertahan dengan mencari alasan yang masuk akal; 2) represi yaitu suatu usaha menekan atau melupakan hal yang tidak menyenangkan; 3) proyeksi yaitu suatu usaha memantulkan ke pihak lain dengan alasan yang dapat diterima.

b. Reaksi menyerang (aggressive reaction)

Orang yang memunyai penyesuaian diri di sekolah yang salah menunjukkan tingkah laku yang bersifat menyerang untuk menutupi kegagalannya, ia tidak mau menyadari kegagalannya. Reaksi yang muncul antara lain: 1) senang membantu orang lain; 2) menggertak dengan ucapan atau perbuatan menunjukkan sikap permusuhan secara terbuka; 3) menunjukkan sikap merusak; 4) keras kepala; 5) balas dendam dan 6) marah secara sadis.

c. Reaksi melarikan diri (escape reaction) 
Reaksi ini orang yang memunyai penyesuaian diri di sekolah yang salah akan melarikan diri dari situasi yang menimbulkan kegagalannya. Reaksi yang muncul antara lain: a) banyak tidur; b) minum-minuman keras; pecandu ganja, narkotika; c) regresi, yaitu kembali pada tingkah laku kekanakkanakan. Misalnya, orang dewasa yang bersikap dan berperilaku seperti anak kecil.

Berdasarkan uraian di atas, penyesuaian diri di sekolah yang salah ditandai dengan berbagai bentuk tingkah laku yang serba salah, tidak terarah, emosional, sikap yang tidak realistik, agresif dan lain sebagainya.

Asrori (2007: 2003), menyebutkan bahwa terdapat beberapa faktor yang memengaruhi proses penyesuaian diri remaja, yaitu: kondisi fisik, kepribadian, proses belajar, lingkungan, agama dan budaya.

a. Kondisi fisik

Seringkali kondisi fisik memunyai pengaruh kuat terhadap proses penyesuaian diri remaja. Aspek-aspek berkaitan dengan kondisi fisik yang dapat memengaruhi penyesuaian diri remaja adalah: (1) heriditas dan konstitusi fisik, (2) sistem utama tubuh, dan (3) kesehatan fisik.

b. Kepribadian

Unsur-unsur kepribadian yang penting pengaruhnya terhadap penyesuaian diri dalah: (1) kemauan dan kemampuan untuk berubah, (2) pengaturan diri, (3) realisasi diri dan (4) inteligensi.

c. Pendidikan

Unsur-unsur penting dalam edukasi/ pendidikan yang dapat memengaruhi penyesuaian diri individu adalah: (1) belajar, (2) pengalaman, (3) latihan dan (4) determinasi diri.

d. Lingkungan

Berbicara mengenai faktor lingkungan sebagai variabel yang berpengaruh terhadap penyesuaian diri remaja meliputi lingkungan keluarga, sekolah dan masyarakat.

e. Agama dan budaya

Agama berkaitan erat dengan budaya. Agama memberikan sumbangan nilai-nilai, keyakinan, praktik-praktik yang memberi makna sangat mendalam, tujuan, serta kestabilan dan keseimbangan hidup individu. Agama secara konsisten dan kontinyu mengingatkan manusia tentang nilai-nilai intrinsik dan kemuliaan manusia yang diciptakan oleh Tuhan; bukan sekedar nilai-nilai instrumental sebagaimana yang dihasilkan oleh manusia.

Prayitno dan Amti (2004: 259-260) menjelaskan layanan informasi ialah kegiatan memberikan pemahaman kepada individu-individu yang berkepentingan tentang berbagai hal yang diperlukan untuk menjalani suatu tugas atau kegiatan, atau untuk menentukan arah suatu tujuan atau rencana yang dikehendaki. Dengan demikian, layanan informasi itu pertama-tama merupakan perwujudan pemahaman dalam bimbingan dan konseling. Hallen (dalam Abidin dan Budiyono, 2010: 40) mengemukakan layanan informasi adalah layanan bimbingan dan konseling yang memungkinkan klien menerima dan memahami berbagai informasi (informasi pendidikan, jabatan dan karir) yang dapat dipergunakan sebagai bahan pertimbangan dan pengambilan keputusan demi kepentingan individu klien.

Winkel (dalam Tohirin, 2007: 147) menguraikan layanan informasi merupakan suatu layanan yang memenuhi kekurangan individu akan informasi yang mereka perlukan. Layanan informasi juga bermakna usaha-usaha untuk membekali siswa dengan pengetahuan serta pemahaman tentang lingkungan hidupnya dan tentang proses perkembangan anak muda.

Berdasarkan uraian di atas, dapat disimpulkan bahwa layanan informasi merupakan layanan bimbingan dan konseling untuk membekali peserta didik sebagai bahan pertimbangan, pengetahuan tentang dirinya dan pengambilan keputusan untuk kepentingan hidup dan perkembangannya. Jika digabungkan, definisi efektivitas dengan layanan informasi menjadi efektivitas layanan informasi adalah sejauh mana layanan informasi mencapai target atau tujuantujuan yang telah ditetapkan sebelumnya.

Tohirin (2007: 147-148) mengemukakan bahwa layanan informasi bertujuan agar siswa mengetahui menguasai informasi yang selanjutnya dimanfaatkan untuk keperluan hidupnya sehari-hari dan perkembangan dirinya. Selain itu apabila merujuk pada fungsi pemahaman. Layanan informasi bertujuan agar individu memahami berbagi informasi dengan segala seluk beluknya. Penguasaan akan berbagai informasi dapat digunakan untuk mencegah timbulnya masalah, pemecahan suatu masalah, untuk memelihara dan mengembangkan potensi individu serta memungkinkan siswa yang bersangkutan membuka diri dalam mengaktualisasikan hak-haknya.

Abidin dan Budiyono (2010: 41-42), 
menyatakan dasar diberikannya layanan informasi yaitu untuk: (1) membekali individu dengan berbagai pengetahuan tentang lingkungan yang diperlukan guna memecahkan masalah yang dihadapi berkenaan dengan lingkungan sekitar, pendidikan, jabatan maupun sosial budaya yang melingkari pengambilan keputusan dan hajat hidupnya. (2) memungkinkan individu dapat membelajarkan diri menentukan arah hidupnya ke manapun yang ingin dituju. Artinya dengan informasi yang jelas ia tahu apa yang harus diberitahukan dan bagaimana harus bertindak kreatif, motivatif, dan dinamis. (3) setiap individu adalah unik artinya dengan keunikan masingmasing individu akan mewujudkan pola pengambilan keputusan hidup yang beragam, begitu pula dalam cara bertindak dengan keanekaragaman tersebut diharapkan dapat menciptakan dinamika perkembangan individu dan masyarakat secara potensial dan positif. (4) masa depan adalah layanan informasi dan telah menjadi kebutuhan mendasar bagi umat manusia, bagi individu yang tidak mengindahkannya, ia akan tertinggal jauh di landasan kehidupan dan kehilangan masa depannya (Prayitno, 2004: 260).

Tohirin (2007: 152) mengemukakan pelaksanaan layanan informasi menempuh tahapan-tahapan sebagai berikut:

1. Perencanaan

Identifikasi kebutuhan akan informasi bagi calon peserta layanan, menetapkan materi sebagai isi layanan, menetapkan subjek penelitian, menetapkan narasumber, menyiapkan prosedur, perangkat dan media layanan dan menyiapkan kelengkapan administrasi.

2. Pelaksanaan

Mengorganisasikan kegiatan layanan, mengaktifkan peserta layanan, mengoptimalkan penggunaan metode dan media.

3. Evaluasi

Menetapkan materi evaluasi, menetapkan prosedur evaluasi, menyusun instrumen evaluasi, mengaplikasikan instrumen evaluasi dan mengolah hasil aplikasi instrumen.

4. Analisis hasil evaluasi

Menetapkan norma atau standar evaluasi, melakukan analisis, menafsirkan hasil analisis.

5. Tindak lanjut

Menetapkan jenis dan arah tindak lanjut, mengomunikasikan rencana tindak lanjut kepada pihak terkait dan melaksanakan rencana tindak lanjut.
6. Laporan

Menyusun laporan layanan informasi, menyampaikan laporan kepada pihak terkait (kepala sekolah), dan mendokumentasikan laporan.

Prayitno dan Amti (2004: 269-271) menjelaskan pemberian informasi kepada siswa dapat dilakukan dengan berbagai cara sebagai berikut:

1. Ceramah

Ceramah merupakan metode pemberian informasi yang paling sederhana, mudah dan murah, dalam arti bahwa metode ini dapat dilakukan hampir oleh setiap petugas bimbingan di sekolah.

2. Diskusi

Penyampaian informasi pada siswa dapat dilakukan melalui diskusi. Diskusi semacam ini dapat diorganisasikan baik oleh siswa maupun oleh konselor atau guru.

3. Karya wisata

Dalam bidang konseling karyawisata memunyai dua sumbangan pokok. Pertama, membantu siswa belajar dengan menggunakan berbagai sumber yang ada dalam masyarakat yang ada dalam masyarakat yang dapat menunjang perkembangan mereka. Kedua, memungkinkan diperolehnya informasi yang dapat membantu pengembangan sikap-sikap terhadap pendidikan, pekerjaan dan berbagai masalah dalam masyarakat.

4. Buku panduan

Buku-buku panduan (seperti buku panduan sekolah atau perguruan tinggi, buku panduan kerja bagi karyawan) dapat membantu siswa dalam mendapatkan informasi yang berguna.

5. Konferensi karir

Selain melalui teknik-teknik yang diutarakan di atas, penyampaian informasi kepada siswa dapat juga dilakukan melalui konferensi karir. Dalam konfrensi karir para narasumber dari kelompok-kelompok usaha, jabatan atau dinas lembaga pendidikan, dan lain-lain yang diundang, mengadakan perjanjian berbagai aspek program pendidikan dan latihan/ pekerjaan yang diikuti oleh para siswa.

\section{Metode Penelitian}

Penelitian ini dilaksanakan di SMP Negeri 1 Loghia Kabupaten Muna. Alasan dipilihnya SMP Negeri 1 Loghia Kabupaten Muna sebagai lokasi penelitian adalah: a) adanya masalah terkait 
penyesuaian diri siswa yang rendah dan b) keterjangkauan lokasi penelitian. Penelitian ini dilaksanakan selama 2 bulan dimulai dari bulan November 2018 sampai dengan Desember 2018. Perlakuan/ treatment dalam penelitian ini dilaksanakan selama 5 kali pertemuan dengan frekuensi pertemuan satu kali seminggu, lamanya satu pertemuan 60 menit.

Penelitian ini adalah penelitian eksperimen dengan pendekatan pra eksperimen. Penelitian praeksperimen adalah penelitian eksperimen yang dilakukan dengan tanpa melakukan pengendalian terhadap variabel-variabel yang berpengaruh. Dalam penelitian ini yang diutamakan adalah pemberian perlakuan saja, tanpa ada kelompok kontrol (Latipun, 2015: 68). Bentuk desain yang digunakan adalah one group pre test and posttest design. Pada desain ini terdapat pre test yaitu pemberian instrumen angket sebelum diberi perlakuan, kemudian diberikan perlakuan yaitu dengan pemberian layanan informasi dan terakhir diberikan posttest yang tujuannya untuk mengetahui apakah perlakuan tersebut dapat meningkatkan penyesuaian diri siswa SMP Negeri 1 Loghia Kabupaten Muna.

Subjek penelitian ditetapkan dengan teknik purposive sampling yaitu menentukan subjek berdasarkan skor inventori penyesuaian diri siswa. Adapun subjeknya adalah sebanyak 19 siswa kelas VII yang memiliki skor rendah atau sangat rendah dari analisis angket penyesuaian diri siswa. Layanan informasi dalam penelitian ini dilaksanakan secara klasikal.

Data dalam penelitian ini dikumpulkan dengan metode wawancara dan angket. Analisis data dilakukan secara deskriptif dan inferensial. Sugiyono (2016: 207) menjelaskan analisis deskriptif persentase adalah statistik yang digunakan untuk menganalisis data dengan cara mendeskripsikan atau menggambarkan data yang telah terkumpul sebagaimana adanya tanpa bermaksud membuat kesimpulan yang berlaku untuk umum atau generalisasi. Metode analisis data secara inferensial yang digunakan adalah dengan menggunakan SPPS 17 yaitu uji wilxocon match pairs untuk mengetahui perbedaan signifikan pre test dan post test menggunakan uji Wilxocon Match Pairs test karena jumlah sampel kurang dari 25 yakni sepuluh atau $\mathrm{n}=10$ dan data berdistribusi tidak normal.

\section{Hasil Penelitian dan Pembahasan Hasil Penelitian}

Analisis deskriptif persentase

Hasil pengolahan data pre test penyesuaian diri siswa, dapat dilihat pada tabel di bawah ini:

Tabel 1

Distribusi Skor Pre test

Frekuensi Penyesuaian Diri Siswa

\begin{tabular}{|c|c|c|c|}
\hline $\begin{array}{c}\text { Interval } \\
\text { Persentase }\end{array}$ & Kategori & Frek. & $(\boldsymbol{\%})$ \\
\hline $81 \%-100 \%$ & Sangat tinggi & 0 & 0 \\
\hline $63 \%-80 \%$ & Tinggi & 0 & 0 \\
\hline $44 \%-62 \%$ & Rendah & 19 & 100 \\
\hline $25 \%-43 \%$ & Sangat rendah & 0 & 0 \\
\hline \multicolumn{2}{|c|}{ Jumlah } & 19 & 100 \\
\hline
\end{tabular}

Berdasarkan data pada Tabel 1 tersebut, terlihat bahwa penyesuaian diri siswa SMP Negeri 1 Loghia sebelum diberikan layanan informasi dengan jumlah subjek penelitian sebanyak 19 siswa, seluruh subjek berada pada kategori rendah yakni berjumlah 19 siswa dengan persentase $100 \%$.

Treatment yang dimaksud dalam penelitian ini adalah pemberian layanan informasi yang dilakukan oleh peneliti sendiri sebanyak 5 kali pertemuan kepada 19 siswa yang menjadi subjek penelitian.Berikut diuraikan rangkaian kegiatan pemberian layanan informasi oleh peneliti di SMP Negeri 1 Loghia. Hasil pengolahan data post test penyesuaian diri siswa, dapat dilihat pada tabel di bawah ini:

Tabel 2

Distribusi Skor Post test Frekuensi Penyesuaian Diri Siswa

\begin{tabular}{|c|c|c|c|}
\hline $\begin{array}{c}\text { Interval } \\
\text { Persentase }\end{array}$ & Kategori & Frek. & $(\boldsymbol{\%})$ \\
\hline $81 \%-100 \%$ & Sangat Tinggi & 3 & 15,79 \\
\hline $63 \%-80 \%$ & Tinggi & 16 & 84,21 \\
\hline $44 \%-62 \%$ & Rendah & 0 & 0,00 \\
\hline $25 \%-43 \%$ & Sangat Rendah & 0 & 0,00 \\
\hline Jumlah & & $\mathbf{1 9}$ & $\mathbf{1 0 0}$ \\
\hline
\end{tabular}

Berdasarkan data pada tabel 2 tersebut, dapat diketahui bahwa secara keseluruhan penyesuaian diri siswa SMP Negeri 1 Loghia sesudah diberikan perlakuan (treatment) yaitu sebanyak 3 siswa dengan persentase $15,79 \%$ dalam kategori sangat tinggi dan 16 siswa dengan persentase $84,21 \%$ 
dalam kategori tinggi. Berikut perbandingan penyesuaian diri siswa antara pre test dan post test dapat dilihat pada tabel berikut:

Tabel 3

Perbandingan Skor Pre test dan Skor Post test Penyesuaian Diri Siswa

\begin{tabular}{|c|c|c|c|c|c|}
\hline \multirow{2}{*}{$\begin{array}{c}\text { L'Wl } \\
\text { For, ta }\end{array}$} & \multirow{2}{*}{$k+4 i$} & \multicolumn{2}{|c|}{$m b x$} & \multicolumn{2}{|c|}{ feta } \\
\hline & & Prt: & (6) & P石 & (6) \\
\hline $81 \%-100 x$ & $S_{p} \pm T_{i j}$ & 0 & 0 & 3 & 1579 \\
\hline $6 \%-8 \%$ & Thio & 0 & 0 & 16 & 8121 \\
\hline $47-6 *$ & Bonth & 19 & 100 & 0 & 0 \\
\hline $2 x-9 x$ & SytRenth & 0 & 0 & 0 & 0 \\
\hline & & 10 & 110 & b & 10 \\
\hline
\end{tabular}

Berdasarkan data pada tabel 3 tersebut, atas diketahui bahwa terjadi peningkatan kategori penyesuaian diri siswa antara pre test dengan post test. Pada hasil pre test kategori penyesuaian diri siswa adalah 19 siswa (100\%) kategori rendah, kemudian setelah diberikan post test meningkat menjadi 3 siswa $(15,79 \%)$ dengan kategori sangat tinggi dan 16 siswa $(84,21 \%)$ dengan kategori tinggi. Terjadi peningkatan kemampuan penyesuaian diri siswa setelah diberikan layanan informasi sebesar sebesar 18,53\%.

Analisis statistik inferensial

Untuk mengetahui efektivitas pemberian layanan informasi terhadap penyesuaian diri siswa sebelum dan sesudah pemberian layanan informasi digunakan rumus Uji Wilcoxon Signed Rank. Berikut hasil uji Wilcoxon Signed Rank Test.

Tabel 4

Uji Wilcoxon Signed Ranks

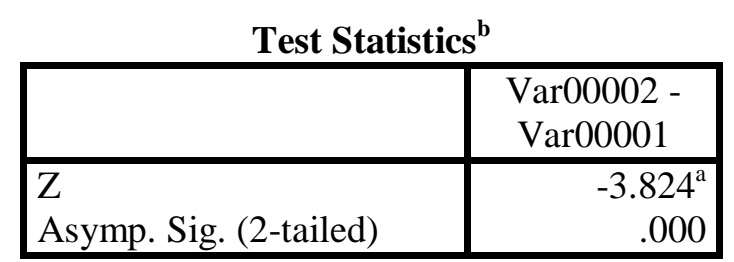

a. Based on negative ranks.

b. Wilcoxon Signed Ranks Test

Berdasarkan Output di atas diperoleh nilai Positif Ranks $=10$ yang berarti nilai seluruh responden kelompok kedua (Post Test) lebih tinggi dari kelompok pertama (Post Test). Sedangkan nilai
Asymp. Sig. (2-tailed) sebesar 0,000. Karena nilai sig. $0,000<0,05$ pada taraf signifikan $5 \%$ atau $\alpha=$ 0,05 , maka dapat disimpulkan bahwa ada perbedaan signifikan penyesuaian diri siswa antara sebelum dan setelah diberikan layanan informasi.

\section{Pembahasan}

Penelitian ini bertujuan untuk mengetahui pengaruh layanan informasi terhadap penyesuaian diri siswa SMP Negeri 1 Loghia. Berdasarkan hasil analisis deskriptif persentase diketahui bahwa penyesuaian diri siswa yang menjadi subjek penelitian sebelum diberikan layanan informasi ( $p r e$ test) adalah 56,97\% termasuk dalam kategori rendah. Kemudian sesudah mendapatkan perlakuan berupa layanan informasi hasil post test subjek penelitian terjadi peningkatan skor persentase menjadi $75,50 \%$ termasuk dalam kategori tinggi. Hal ini menunjukkan bahwa informasi dalam bimbingan dan konseling dapat meningkatkan penyesuaian diri siswa.

Hasil Uji Wilxoson Signed Rank Test diperoleh nilai Positif Ranks $=10$ yang berarti nilai seluruh responden kelompok kedua (Post Test) lebih tinggi dari kelompok pertama (Pre Test). Sedangkan nilai Asymp.Sig. (2-tailed) sebesar 0,000 . Karena nilai sig. $0,000<0,05$ pada taraf signifikan $5 \%$ atau $\alpha=0,05$, maka dapat disimpulkan bahwa ada perbedaan signifikan penyesuaian diri siswa antara sebelum dan setelah diberikan layanan informasi.

Hasil penelitian ini menegaskan kembali hasil penelitian yang dilakukan oleh Anisa (2017) dengan judul meningkatkan penyesuaian diri di sekolah melalui layanan bimbingan kelompok pada siswa kelas XI SMA Negeri 1 Abung Semuli Tahun Pelajaran 2016/ 2017. Hasil penelitian ini menunjukkan terdapat peningkatan yang signifikan pada penyesuaian diri sebelum dan sesudah diberi layanan bimbingan kelompok. Peningkatan tersebut sebesar 26\%. Kesimpulannya adalah penyesuaian diri dapat ditingkatkan melalui layanan bimbingan kelompok pada siswa SMA Negeri 1 Abung Semuli TahunPelajaran 2016/ 2017.

Hallen (dalam Abidin dan Budiyono, 2010: 40) mengemukakan layanan informasi adalah layanan bimbingan dan konseling yang memungkinkan klien menerima dan memahami berbagai informasi (informasi pendidikan, jabatan, karir) yang dapat dipergunakan sebagai bahan pertimbangan dan pengambilan keputusan demi kepentingan individu klien. sedangkan Winkel (dalam Tohirin, 2007: 147) menguraikan layanan 
informasi merupakan suatu layanan yang memenuhi kekurangan individu akan informasi yang mereka perlukan. Layanan informasi juga bermakna usahausaha untuk membekali siswa dengan pengetahuan serta pemahaman tentang lingkungan hidupnya dan tentang proses perkembangan anak muda.

Pemahaman siswa tentang diri dan lingkungannya sangat penting agar anak dapat menempatkan diri dan melakukan upaya-upaya yang produktif sesuai dengan harapan masyarakat. Layanan informasi dalam bimbingan dan konseling memiliki tujuan sebagaimana dikemukakan oleh Prayitno dan Amti (2004: 120) menyatakan bahwa layanan informasi bertujuan untuk:

1. Membekali individu dengan berbagai macam pengetahuan tentang lingkungan yang diperlukan untuk memecahkan masalah yang dihadapi berkenaan dengan lingkungan sekitar, pendidikan, jabatan, maupun sosial budaya.

2. Memungkinkan individu dapat menentukan arah hidupnya "kemana ingin pergi". Syarat dasar untuk dapat menentukan arah hidup adalah apabila mengetahui apa (informasi) yang harus dilakukan serta bagaimana bertindak secara kreatif dan dinamis berdasarkan atas informasiinformasi yang diberikan itu.

3. Setiap individu adalah unik, memberikan pemahaman tentang diri siswa yang secara psikologi unik, berbeda antara satu dengan yang lain, dalam berbagai hal juga berbeda. Dengan perbedaan dan keunikan ini maka pengembangan diri dan kemampuannya juga berbeda-beda.

Dengan diberikannya layanan informasi secara sistematis oleh peneliti sebanyak 5 kali pertemuan, terbukti skor penyesuaian diri siswa mengalami peningkatan. Layanan informasi dapat membekali individu dengan berbagai informasi dan pengetahuan tentang dirinya dalam pengambilan keputusan hidup. selain itu untuk membuktikan bahwa layanan informasi meningkatkan pemahaman siswa terhadap potensi diri dan merupakan kebutuhan yang amat tinggi tingkatannya, dan juga pemberian informasi yang relevan sesuai daya tangkap dan pengetahuan siswa sehingga dalam perencanaan dan pengambilan keputusan menjadi tepat dan benar.

Melalui pemberian layanan informasi diharapkan siswa menjadi terpacu untuk mengembangkan diri terutama bagi siswa yang memiliki tingkat penyesuaian diri yang rendah. Siswa tersebut informasi dan pengetahuan sehingga ia dapat melakukan introspeksi dan berusaha untuk mampu menghadapi kesulitan yang dialami. Peningkatan penyesuaian diri terhadap lingkungan sekolah melalui media layanan informasi yang terencana akan lebih efektif karena didalamnya melibatkan teman sebaya sehingga dalam penyampaian materi maupun saat ada diskusi tidak ada rasa canggung. Dengan demikian pemahaman siswa menjadi lebih baik tentunya dengan arahan dari narasumber atau pemateri (dalam Nurfuad, 2013: 44).

\section{Kesimpulan dan Saran Kesimpulan}

Berdasarkan hasil penelitian dan pembahasan, ditarik kesimpulan sebagai berikut:

1. Hasil analisis statistik deskriptif menunjukkan pemberian layanan informasi berpengaruh dalam meningkatkan penyesuaian diri siswa dengan nilai peningkatan sebesar $18,53 \%$.

2. Hasil analisis inferensial dengan Uji Wilxoson Signed Rank menunjukkan nilai Asymp. Sig. (2tailed) sebesar 0,000. Karena nilai sig. 0,000< 0,05 pada taraf signifikan $5 \%$ atau $\alpha=0,05$, maka dapat disimpulkan bahwa ada perbedaan signifikan penyesuaian diri siswa antara sebelum dan setelah diberikan layanan informasi.

\section{Saran}

Berdasarkan hasil penelitian yang telah diperoleh pada penelitian ini, saran yang dapat diberikan peneliti adalah:

1. Untuk Siswa, layanan informasi yang berupa pemberian materi sebanyak 5 kali pertemuan penting untuk dipahami dan diimplementasikan dalam keseharian baik saat di lingkungan sekolah maupun di lingkungan masyarakat sehingga penyesuaian dirinya semakin meningkat.

2. Bagi guru BK, hendaknya dapat menggunakan layanan informasi sebagai salah satu layanan bimbingan dan konseling yang cukup efektif dalam upaya penanganan masalah siswa khususnya masalah penyesuaian diri dan masalah lainnya terkait upaya pengembangan diri.

3. Bagi sekolah, agar memerhatikan siswa-siswa yang mengalami masalah seperti masalah penyesuaian diri. Karena dapat berdampak buruk jika diabaikan, serta dapat semakin memberikan dukungan terhadap program 
bimbingan dan konseling terutama berupa layanan bagi siswa

4. Bagi peneliti selanjutnya, hasil penelitian ini diharapkan dapat memberikan kontribusi teoritis dan dapat dimanfaatkan oleh peneliti lainnya sebagai salah satu acuan dalam mengaji dan mengembangkan penelitian lanjutan yang relevan.

\section{Daftar Pustaka}

Anisa, Riska Nur. (2017). Meningkatkan penyesuaian diri di sekolah melalui layanan bimbingan kelompok pada siswa kelas XI SMA Negeri 1 Abung Semuli Tahun Pelajaran 2016/ 2017. Skripsi: Universitas Lampung.

Ali, Mohammad \& Mohammad Asrori. (2008). Psikologi Remaja: Perkembangan Peserta Didik. Jakarta: PT. Bumi Aksara.

Asrori, Mohammad. (2008). Psikologi Pembelajaran. Bandung: CV. Wacana Prima.

Astuti, A.B. (2000). Hubungan Antara Dukungan Keluarga Dengan Penyesuaian Diri Perempuan Pada Kehamilan Pertama. Jurnal Psikologi 2000 No. 2. Halaman 84-95.

Fatimah, Enung. (2006). Psikologi Perkembangan: Perkembangan Peserta Didik,. Bandung: Pustaka Setia.

Latipun. (2006). Psikologi Eksperimen. Malang: UMM Press.

Prayitno. (2004). Layanan L.1-L.9. Padang: Jurusan BK FIP Universitas Negeri Padang.

Prayitno dan Erman Amti. (2004). Dasar-dasar Bimbingan dan Konseling. Jakarta: Rineka Cipta.

Rahayu, Sri. (2012). Hubungan Layanan Informasi dengan kreativitas belajar siswa. Jurnal Ilmiah Pendidikan Bimbingan dan Konseling. Semarang: IKIP Veteran.

Semium, Y. (2006). Kesehatan Mental 1: Pandangan Umum Mengenai Penyesuaian Diri dan Kesehatan Mental serta Teori-teori Terkait. Yogyakarta: Kanisius.
Sukardi, Dewa Ketut dan Desak Made Sumiati. (2009). Pedoman Praktis Bimbingan dan Penyuluhan di Sekolah. Denpasar: Rineka Cipta.

Tohirin. (2007). Bimbingan dan Konseling di Sekolah dan Madrasah (Berbasis Integrasi). Jakarta: Raja Grafindo Persada.

Undang-undang Republik Indonesia No. 20 tahun 2003 tentang Sisdiknas. Jakarta: Depdiknas.

Walgito, Bimo. (2004). Pengantar Psikologi Umum. Yogyakarta: Andi Offset.

Wardani, Silvia Yula dan Rischa Pramudia Trisnani (2017). Efektifitas Layanan Informasi untuk Meningkatkan Pemahaman Karier Siswa SMA Negeri 1 Wungu. Jurnal Konseling GUSJIGANG Vol. 3 No.2 Juli-Desember 2017: Universitas PGRI Madiun.

Winkel, W.S. (2012) Bimbingan Dan Konseling Di Institusi Pendidikan. Jakarta: PT. Grasindo.

Willis, Sofyan S. (2008). Remaja dan Masalahnya. Bandung: Alfabeta. 